\title{
Bionomina, a forum for biological terminology and nomenclature: the first 10 years
}

\author{
Alain Dubois \& Annemarie OHLER \\ Institut de Systématique, Évolution, Biodiversité (ISYEB), Muséum national d'Histoire naturelle, Sorbonne Université, \\ École Pratique des Hautes Études, Université des Antilles, CNRS, 57 rue Cuvier, CP 30, F-75005 Paris, France.

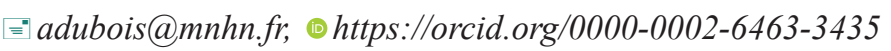 \\ ”"annemarie.ohler@mnhn.fr, ○https://orcid.org/0000-0001-6531-464X; Phone: +33 140793486
}

The first issue of the journal Bionomina was published by Magnolia Press (Auckland, New Zealand) on 24 December 2010. The journal originated from an evolution and expansion of the section 'Theory and methodology' introduced in 2006 in the journal Zootaxa, itself founded in 2001 (Zhang 2007). The purpose of this new journal was wider than that of this section, being presented as "to open a space of free discussion among colleagues involved in or interested in all aspects of the terminology of comparative and evolutionary biology, including, but not limited to, taxonomy and nomenclature of taxa" (Dubois 2010: 8).

The journal was launched by a group of 26 biologists, linguists, epistemologists and philosophers from 15 countries (Australia, Austria, Belgium, Canada, China, Columbia, France, Germany, Italy, New Zealand, Russia, Sweden, Switzerland, UK, USA). From the start, it has been aimed at being an open forum, free of any censorship, for the discussion of sensible questions concerning the use of language and words in all disciplines of biology, for the confrontation of opinions and proposals.

Although biologists, like all scientists, must necessarily use discipline-specific terminology, many of them are reluctant to devote time and energy to the proper consideration of the origin and meaning(s) of these words. Furthermore, many journals are reticent to publish debates or contradictory papers about questions of biological language and terminology, as well as about the theory of nomenclature. These attitudes result in frequent problems of communication, first among biologists themselves and then between them and other scientists or non-scientists (Kuhn \& Wahl-Jensen 2010). The journal Bionomina was intended to contribute to a change of mind in this respect among the community of biologists and other scientists interested in the language of the life sciences.

The journal was initially conceived as liable to accept papers dealing with two main domains: the one, general, covering the languages and terminologies used in all branches of biology; the other, more specialised, being the nomenclature of taxa, according to precise and codified rules, in all the branches of the tree of life. During the first ten years of its development, its success was uneven in these two domains, as we will see.

\section{Issues published}

From the start, the journal Bionomina has been published simultaneously in two versions, on paper and online as PDFs, with different ISSNs (1179-7649 for the print edition and 1179-7657 for the online edition), having exactly the same content and format. The journal does not have a fixed 

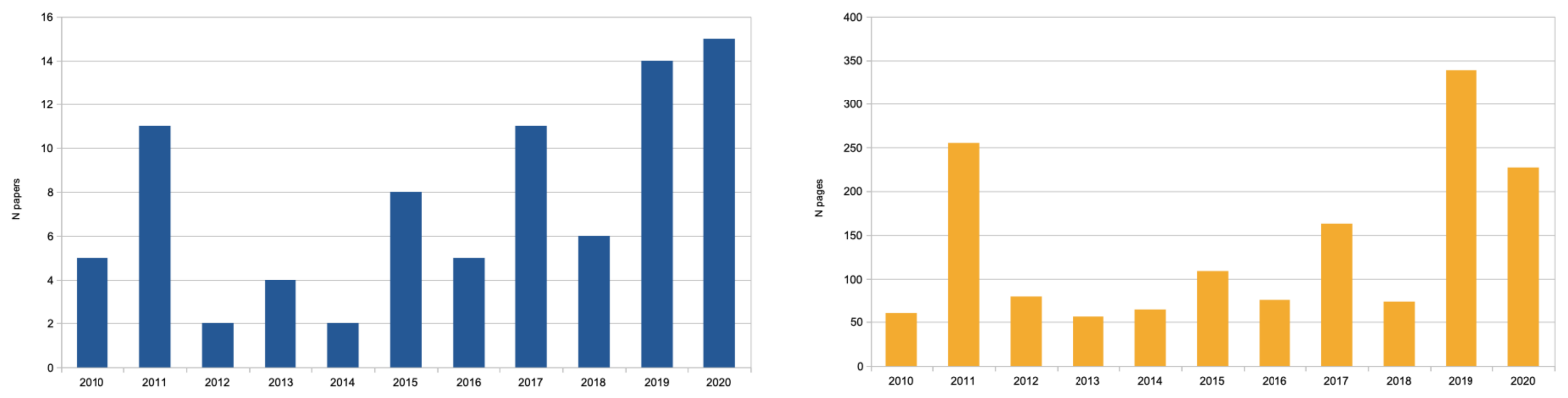

A

B
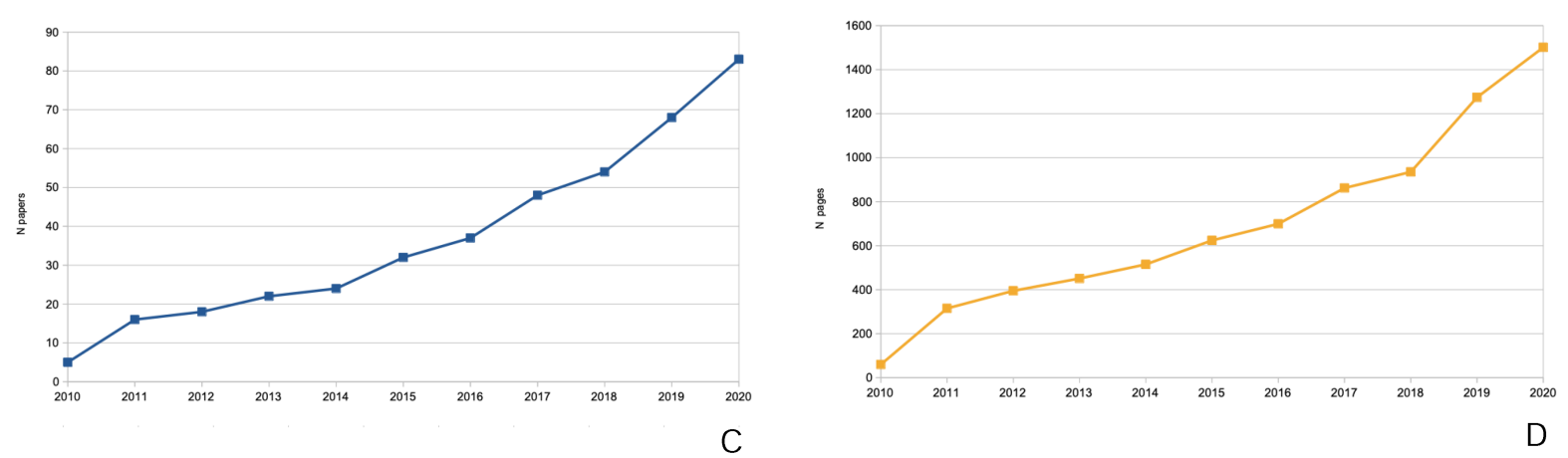

FIGURE 1. Histograms and curves showing the numbers of papers and pages published yearly from 2010 to 2020 in issues 1-20 of Bionomina.

A, histogram of number of papers. B, histogram of number of pages. C, cumulative curve of number of papers. D, cumulative curve of number of pages.

periodicity, each issue being published as soon as a minimum number of pages is reached, in order to reduce the costs of printing, binding and mailing to subscribers of the paper version.

Appendix 1 below gives the list of volumes and papers published in Bionomina from 24 December 2010 to 31 December 2020. These represent 20 volumes, including 83 papers and covering 1501 pages. As shown in Appendix 2, Table 1 and in Figure 1, the number of issues per year has varied from 1 (in 2010, 2012, 2013, 2014, 2016, 2018) to 4 (in 2019), the number of papers per year from 2 (in 2012 and 2014) to 15 (in 2020), the number of pages per year from 56 (in 2013) to 339 (in 2019), and the number of pages per paper from 1 to 111 .

The 83 papers include 59 articles $(71.1 \%), 16$ correspondences $(19.3 \%), 3$ monographs $(3.6 \%)$, 3 editorials (3.6\%) and 2 book reviews $(2.4 \%)$.

\section{Authors and countries}

Over these 10 years, 88 authors working in 19 countries and in the 6 main regions of the world have contributed to the 83 papers published in the journal (see Appendix 2, Table 2 and Figure 2). The highest numbers of contributors worked in Brazil (18), France (18) and the USA (13) but, on the whole, more than half (48) of the authors worked in Europe.

The number of authors per paper varied from 1 to 11 , with a median of 1 (first quartile 1, third quartile 2). 


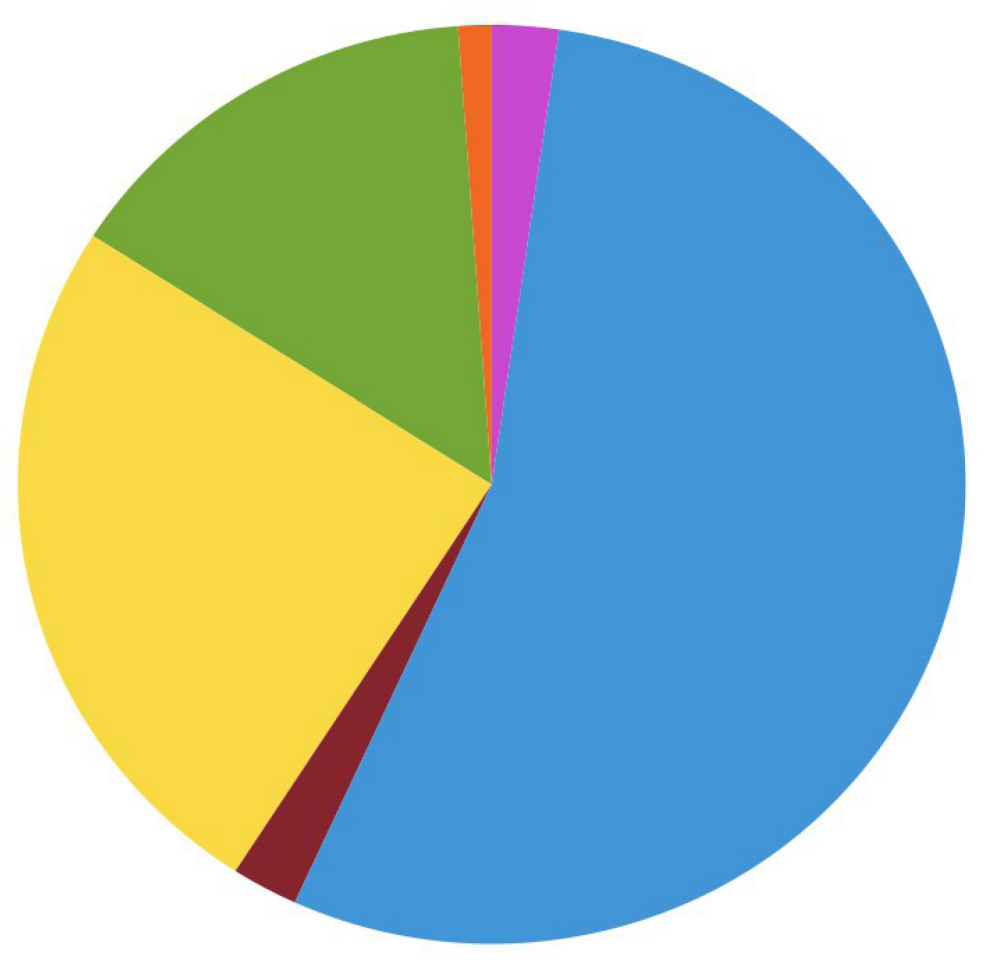

\author{
- Africa \\ - America (North) \\ America (South) \\ - Asia \\ Europe \\ - Oceania
}

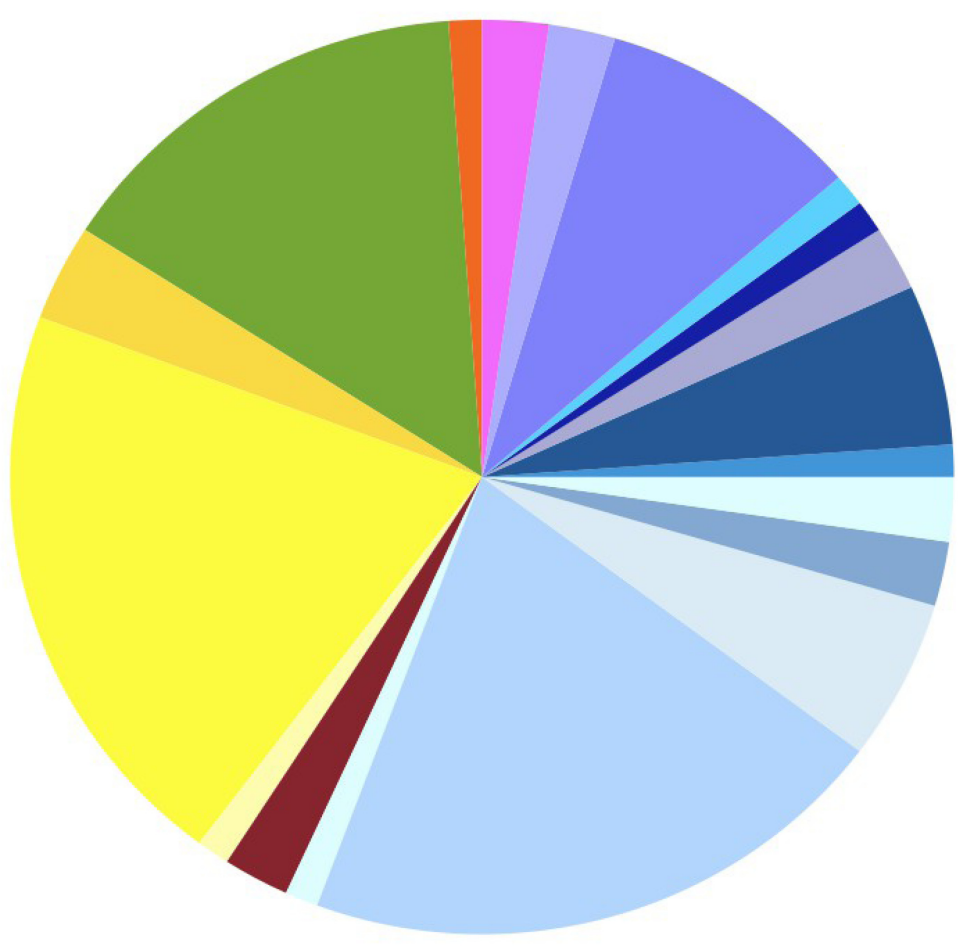
- South Africa
USA
Argentina
Brazil
Ecuador
- Japan
Austria
France
Germany
Italy
Poland
- Portugal
- Russia
Spain
- Sweden
switzerland
UK
Ukraine
Australia

A

FIGURE 2. Geographical origin of the authors of the 83 papers published from 2010 to 2020 in issues $1-20$ of Bionomina.

A, distribution of the authors according to the main regions of the world where they worked. B, distribution of the authors according to the countries where they worked. 


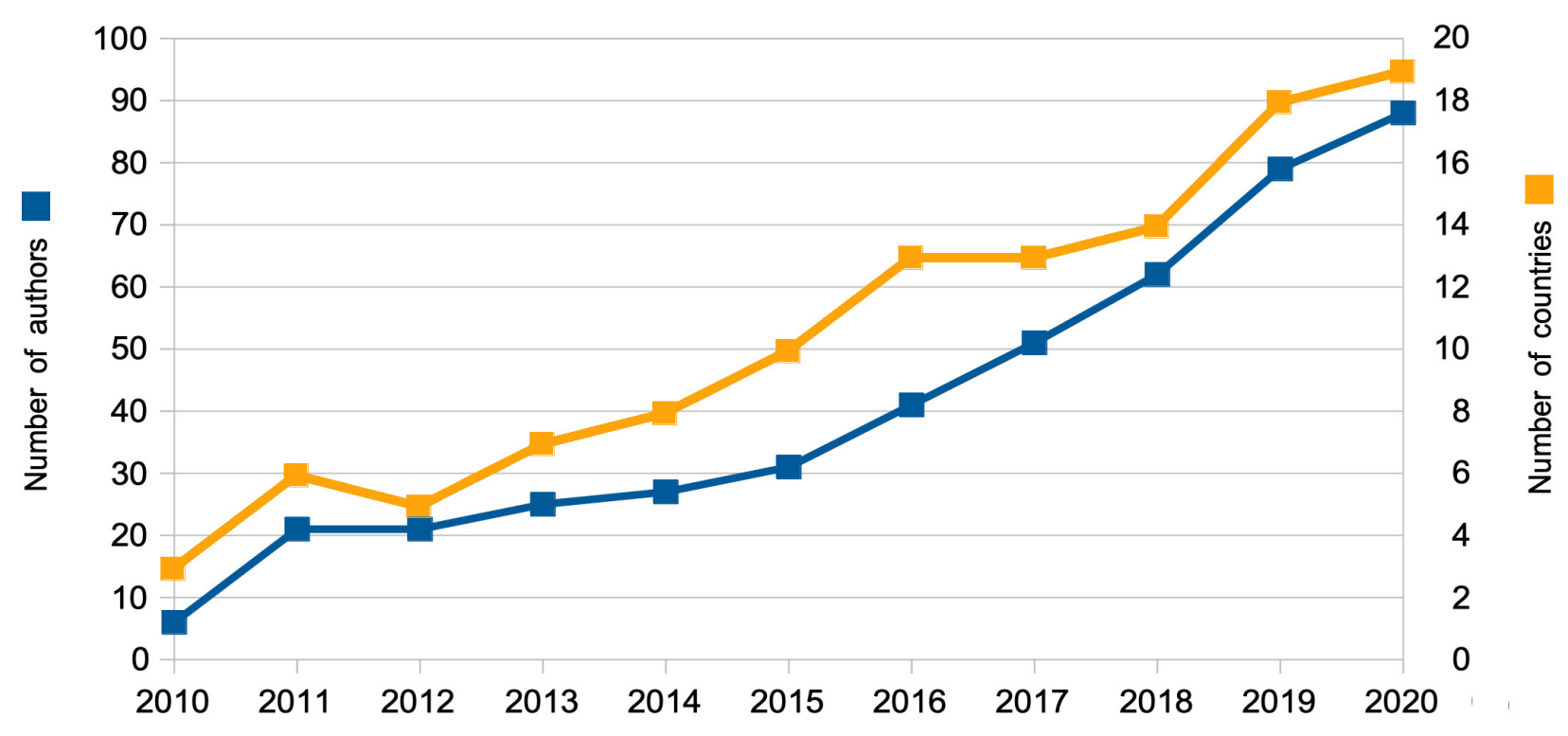

FIGURE 3. Cumulative curve showing the numbers of authors of papers published from 2010 to 2020 in issues 1-20 of Bionomina and of countries where these authors worked.

Blue, authors. Orange, countries.

There was a regular increase over the years in the number of authors publishing in the journal, as well as in the number of countries where these authors were working (Figure 3).

Eleven Corresponding Editors from six countries cared for the reviewing and accepting (or rejecting) the manuscripts submitted to the journal. The delay between submission and acceptance of a paper straddled from 0 to 615 days, with a median of 65 days (first quartile 16; third quartile 189.5) and that between acceptance and publication from 6 to 616 days, with a median of 37 days (first quartile 24.5; third quartile 94).

\section{Main topics}

The two main domains for which the journal was initially devised were very unevenly represented in the 83 papers published: whereas 71 papers $(85.5 \%)$ dealt with nomenclature, only $9(10.8 \%)$ dealt with terminology, including problems of translation (4 concerning evolution, 3 biology, 1 zoology; 1 common language), and 3 (3.6\%) covered both fields. Furthermore, the trend over the years was clearly towards the increase of the proportion of papers dealing with nomenclature, at the expense of those dealing with terminology (Figure 4). 


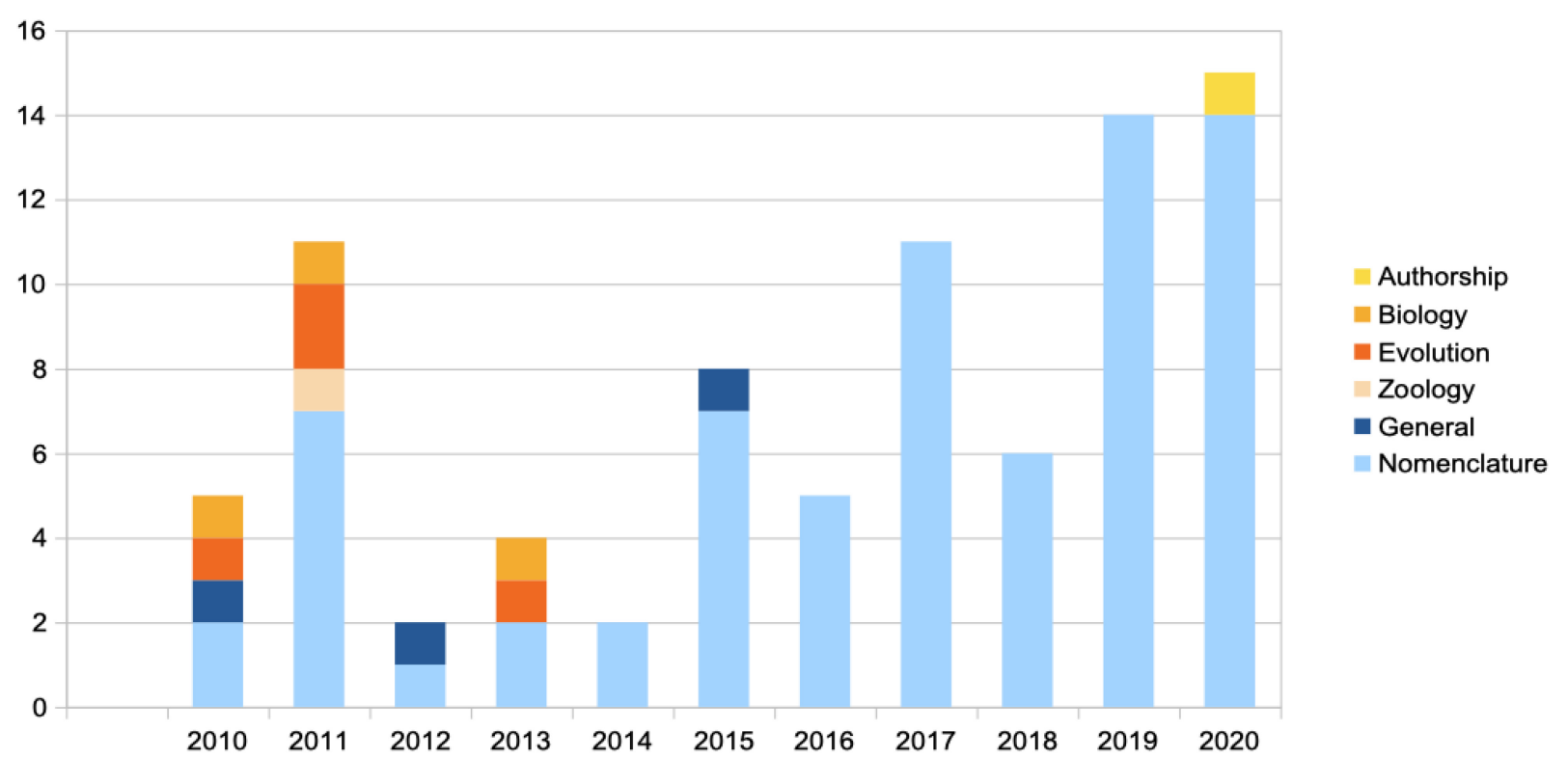

FIGURE 4. Histograms showing the numbers of the 83 papers published from 2010 to 2020 in issues 1-20 of Bionomina according to their main topics: nomenclature, terminology (authorship, biology, evolution, zoology), or both (general).

\section{Nomenclatural topics}

On the whole, 74 papers dealing with biological nomenclature were published in Bionomina from 2010 to 2020 . They can be sorted into several categories according to various criteria.

The first dichotomy is between papers addressing theoretical and practical (applied) aspects of the discipline: $23(31.1 \%)$ of them were dealing with the first domain, $28(37.8 \%)$ with the second one, and $23(31.1 \%)$ with both. This proportion evolved with time (Figure 5). In the first 10 volumes (2010-2016) of the journal, 8 (27.6\%) of the 29 nomenclatural papers discussed mostly theoretical question (using sometimes examples to support their author's ideas or proposals), 14 (48.3\%) both questions, and only $7(24.1 \%)$ of them were devoted to practical nomenclatural problems. These proportions changed in the last 10 volumes (2017-2020), with 15 (33.3\%) theoretical papers, 9 (20\%) dealing both with theory and practical cases, and 21 (46.7\%) papers dealing with precise nomenclatural cases among the 45 nomenclatural papers then published.

Whereas $7(9.5 \%)$ of these 74 papers discussed general questions of nomenclature, across taxonomic groups, 66 (89.2\%) were concerned with zoological nomenclature, and a single one (1.4\%) with virus nomenclature, but none addressed the nomenclature of plants, algae, fungi, bacteria and cultivated plants. Table 3 (in Appendix 2) shows the main zoological higher taxa discussed in the 40 papers ( $60.6 \%$ of the 66 papers dealing with zoological nomenclature) addressing precise questions regarding the taxonomy and nomenclature of particular zoological groups.

As detailed in Table 4 (in Appendix 2), most aspects of zoological nomenclature were addressed in the 66 papers devoted to this discipline: general questions (including the current governance of the discipline by the Code and the Commission); questions specific to the three main stages of the nomenclatural process (Dubois 2005), namely nomenclatural availability of new publications, new nomina (scientific names) and other nomenclatural novelties (including nominal-series assignment), taxonomic allocation of nomina and nomenclatural validity of nomina (including spelling correctness) 
and nomenclatural acts; recommendations and ethics; and other nomenclatural systems. In these papers, 22 taxonomic and nomenclatural novelties were introduced, including 8 new taxa and their nomina, 1 new replacement nomen, 2 subsequent designations of types (onomatophores), 1 new combination, 1 spelling emendation and 9 validations of nomina through reversal of precedence under the Code or through sozodiaphonym validation under the Duplostensional Nomenclatural System (Dubois 2015b).

These 66 papers, therefore, covered the entire broad field of the discussions that currently concern the international community of taxonomists. Hence, Bionomina has become, in ten years, a key player in these debates and its impact appears to be destined to grow in the coming years.

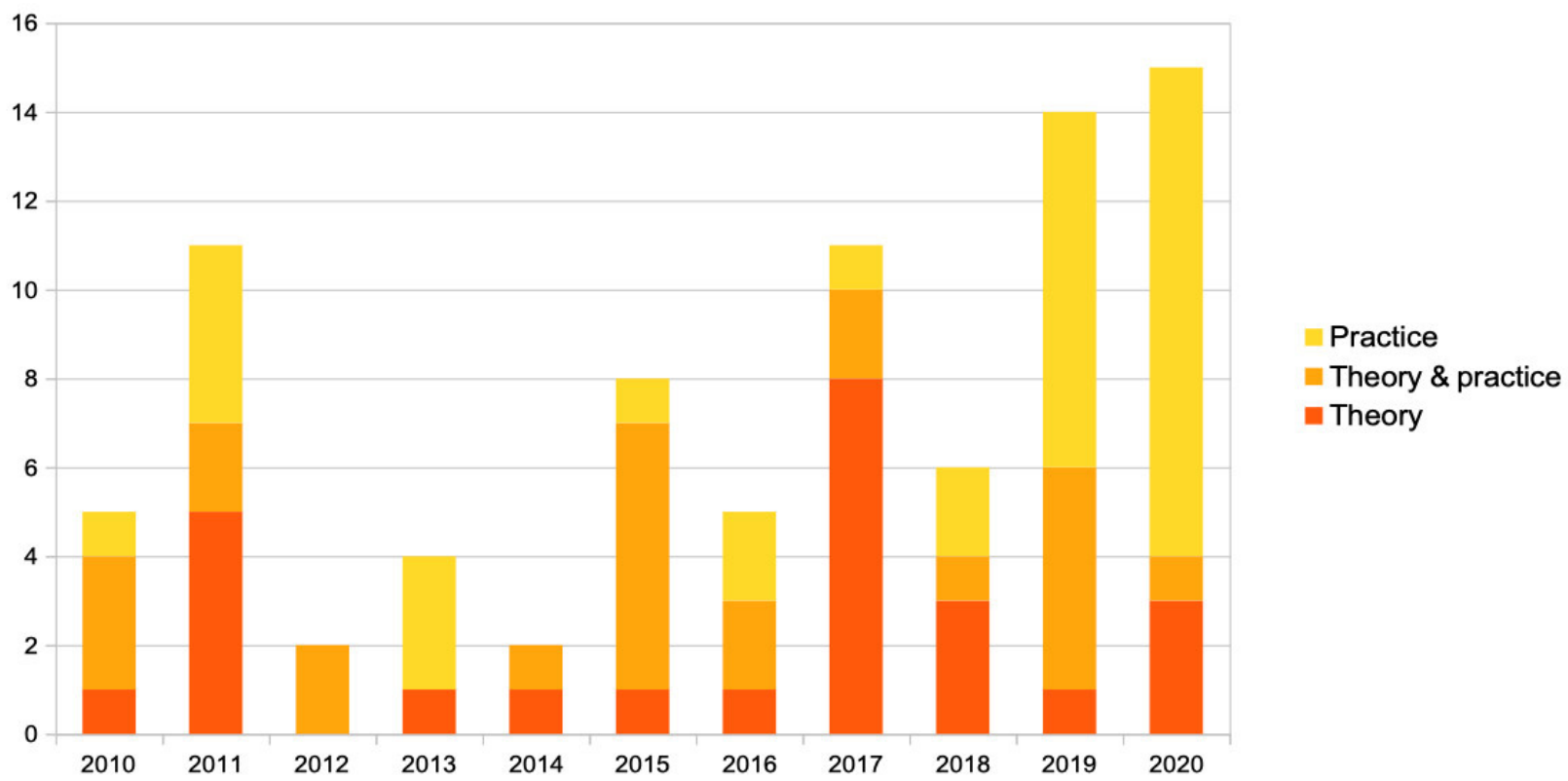

FIGURE 5. Histograms showing the numbers of the 74 papers dealing with biological nomenclature published from 2010 to 2020 in issues 1-20 of Bionomina according to their approach of nomenclature: theoretical, practical or both.

\section{Impact}

The growing impact of Bionomina on the community of zootaxonomists can be appraised through the curves shown in Figure 3, which show that the number of authors and of countries where these authors were working has been slowly but regularly growing across the years.

The numbers of citations per paper, retrieved on 30 April 2021 from Google Scholar $(<\mathrm{https}: / /$ scholar.google.fr/ $>$ ), although low, also testifies to the usefulness of these works for the community. Among the 83 papers, only 14 had no recorded citation at that date. The total number of citations of these papers amounted to 618 , ranging from 0 to 74 (first quartile 1; median 3; third quartile 8) per paper. Of course, this number is higher for the papers published in the first 10 volumes of the journal (2010-2016) than for the more recent last 10 volumes (2017-2020), as shown in Table 5 (in Appendix 2). Table 6 (in Appendix 2) lists the 17 papers which had obtained 10 or more citations by that date. 


\section{Discussion}

\section{Main topics of the papers submitted to Bionomina}

From the early days of biological classification of organisms by the middle of the $18^{\text {th }}$ century, marked by the works of Carolus Linnaeus (1707-1778), biologists have provided scientific names (nomina) for the classificatory units (taxa) they recognised. As stated by Melville (1995: 5), "The essence of the Linnaean revolution was the recognition that the function of the specific 'name' was merely to label a concept rather than to describe an entity". Initially, the fields of taxonomy and nomenclature were closely intermingled, but they became progressively largely independent, and nomenclature became a discipline of its own with the establishment of several international codes dealing with the naming of different categories of taxa (animals, plants, algae and fungi, bacteria, viruses, breeds of cultivated plants, but not breeds of domesticated animals). After a long period of stasis, this discipline has seen an important renewal, with the emergence of new concepts and paradigms for the naming of taxa, devised in particular to account for the fact that the diversity of organisms results from the phenomenon of biological evolution. Several proposals aiming at 'revolutionising' biological nomenclature developed in the last decades of the $20^{\text {th }}$ century and the first years of the present one. Although in zoology and 'botany' (including the study of algae and fungi) an overwhelming majority of working taxonomists currently still follow the 'traditional' codes, no consensus has yet been reached over the whole taxonomic community regarding the 'best' nomenclatural system, in particular because different criteria are used by different 'schools' to evaluate their respective 'qualities'.

The debates concerning these proposals are important for all biological sciences, as all biologists and non-biologists use the 'labels' provided by nomina to designate the classificatory units recognised today by taxonomists on the basis of the available data concerning evolution and phylogenesis. In order for the communication among biologists, as well as between them and society as a whole, to be unambiguous and universal, the relationships between our current phylogenetic and taxonomic concepts and our hypotheses (taxa) on one hand, and their nomina on the other, must be regulated by explicit, precise and binding rules. If, as it is currently the case, several distinct, and partially incompatible, nomenclatural systems are used by different groups of taxonomists and evolutionary biologists, the epistemological bases and idiosyncrasies of these different systems must be clearly understood by all - pending a resolution of these conflicts which is certainly desirable but still far from being reached (Dubois 2011; Aescht 2018).

For such discussions and clarifications, the traditional biological journals, including those focused on evolutionary biology and even many of those specialised in systematics and taxonomy, do not provide appropriate outlets. With the exception of Taxon and of the Bulletin of Zoological Nomenclature discussed below, most of these journals are reluctant to publish papers dealing with these questions, or when they accept to publish them, they often require drastic shortening of discussions or apply censorship to manuscripts presenting unconventional ideas or proposals. The shortage of competent editors and referees, having both a good knowledge of the theory and an experience as practitioners of the codes of nomenclature currently in effect, certainly plays a role in this situation. Yet, the complexity of the questions related to biological nomenclature cannot be artificially ignored or 'administratively' silenced, and their understanding and disentangling often requires extensive, carefully crafted arguments. It also demands very careful editorial work, with back and forth communication between editors, referees and authors, to solve all complex problems, requiring often to go back to original publications which may be of difficult access. All these constraints explain the unusual delays of acceptance for some papers, which is not a problem per se: the time of biological nomenclature is not that of 'speed science', and in this domain accuracy and long-term reliability are much more important than quickness of publication. 
Since its beginnings, Bionomina has attracted mostly manuscripts dealing with zoological nomenclature. It has received a single manuscript dealing with virus nomenclature, none with the nomenclature of bacteria, cultivated plants or even breeds of domesticated animals, for which no code exists but which could be addressed in this journal. This may be due to the fact that the specialists of this questions are using other journals. Particularly striking is the fact that Bionomina has not received a single manuscript dealing with the nomenclature of algae, plants and fungi. This has probably a very simple explanation: the journal Taxon, currently published by the Wiley Online Library on behalf of the International Association for Plant Taxonomy, and which has existed since 1951, appropriately covers this domain and is even the proper place to publish proposals to amend the code of nomenclature for algae, fungi and plants. Nevertheless, Bionomina remains open to papers in this domain.

The Bulletin of Zoological Nomenclature (the BZN), published by the International Commission on Zoological Nomenclature (the Commission), plays a related role regarding zoological nomenclature but functions differently, being the 'official journal' of the Commission and not an independent scientific journal handled by an independent scientific society and editorial board. Its number of pages is limited, which does not allow it to publish long discussion papers on difficult problems affecting zoological nomenclature, and such papers have to find their way elsewhere. Strangely, most of its space (and, by the way, most of the work of the Commission) is devoted to the reversal of precedence concerning some 'well-known' nomina, which often are only known by a handful of specialists, and this journal has long been known for its long publication delays and a questionable editorial policy.

Bionomina is an independent journal, not the organ of a society or official body. As such, it has from the start accepted to publish different opinions, without censorship, and has never limited the length of papers. This has allowed this journal to address in detail some controversial problems of zoological nomenclature, such as the debates between widely different paradigms of this discipline, some basic problems of the zoological Code and of some decisions of the Commission, or the nomenclature of higher taxa (see Appendix 1). In particular, it has devoted many papers to several persistent questions regarding the concept of nomenclatural availability and the related concepts of authorship and date, regarding the modes of production and distribution (including theses and online publications), or regarding the requirement of reference specimens for the description of new species.

Several initial aims of the journal had to be re-evaluated during these first ten years. The paucity of manuscripts dealing with problems of terminology in biology submitted to Bionomina probably reflects the fact that linguists, epistemologists and philosophers are using other outlets for their works, despite the presence of several biologists, epistemologists and philosophers in its editorial board. This interpretation is supported by the fact that several papers in this domain published initially in Bionomina were later 're-published' (with our agreement and mention of the original source) in books or other journals, clearly because in Bionomina they experienced difficulties finding their audience. Therefore, although Bionomina will remain open to such works, for the time being they cannot be expected to become numerous in the journal.

On the other hand, a striking fact that had not been foreseen at the foundation of the journal was that, progressively, it started to attract manuscripts dealing with practical, applied problems related to the availability, authorship, taxonomic allocation, validity and spelling of nomina in various zoological groups. This movement may result from the difficulty to publish such, often quite long and technical, papers in traditional journals of zoological taxonomy, the editors of which do not always have the required expertise to deal appropriately with such complex questions. A rigid attitude sticking to the initial aim of publication of only theoretical papers about nomenclature would have missed the fact that these submissions reflect a genuine need of the community of zootaxonomists, and that this need deserves to be satisfied - and also that often dealing seriously with practical questions leads to a critical re-examination of the current rules and to proposals for their improvement, which requires to address theoretical questions. It is noteworthy that on several occasions Bionomina published papers 
rectifying nomenclatural errors recently published in other journals specialised in zootaxonomy but not so much in zoological nomenclature. This may be due to the fact that often editors of such journals are excellent specialists of the taxonomy of the groups studied in the submitted manuscripts, but not so fluent in the intricacies of nomenclatural rules. In the light of this experience, it is clear that Bionomina occupies a special position among biological journals and is able to render unique services to the taxonomic community.

\section{Authorship}

An interesting fact attracts attention when the list of 83 papers published over 10 years in Bionomina is examined: this is the number of authors of these papers. As shown in Table 7 (in Appendix 2), in 79 of these papers this number was limited to 1,2 or 3 , in two of them it was four, in one of them it was 10 and in one of them it was 11 . The median of this sample is 1 and its mode 1 . This is different from what is observed in zootaxonomic journals publishing mostly taxonomic papers but few purely nomenclatural ones, exemplified in Table 7 by the journal Zootaxa. In a random selection of papers published in the latter journal during the same period (2011-2020), the number of authors straddled from 1 to 13, with a median of 2 and a mode of 2. According to the non-parametric Mann-Whitney $U$ test, the difference between the distributions of these two samples is significant $(W=2491 ; P=$ $3.255^{-10}$ ). The difference is even stronger when Bionomina is compared with journals publishing in the field of molecular phylogenetics, some papers of which also propose taxonomic revisions, new nomina and nomenclatural acts. Such journals are exemplified in Table 7 by a random sample for 2011-2020 of Molecular Phylogenetics and Evolution, showing a range of 1-17 authors, a median of 5 and a mode of 3, which is significantly different both from Bionomina $\left(W=1030.5 ; P=2.2^{-16}\right)$ and from Zootaxa $\left(W=10546 ; P=2.903^{-10}\right)$.

These differences in authorship reflect a recent evolution of the concept and practice of authorship in all scientific publications, including taxonomic ones. For more than two centuries, few scientific papers were signed by more than three authors, and the vast majority of them were signed by single authors. In most cases, the authors of such papers had conceived the study, carried out this study themselves (sometimes with technical help which was then taken for granted) and written the text reporting the study, its results and its conclusion. The help received from collectors of specimens in the field or for technical assistance in the laboratory, if mentioned at all, was so in the acknowledgements of the paper or through dedication of the new taxa to them in using their names as the stems of the new nomina. This was the case of most taxonomic works until late in the $20^{\text {th }}$ century.

Such practices then changed drastically as a result of two main phenomena. The first one, very general, common to taxonomic works and those in many other research fields, was the increase of collaborative studies between researchers and research teams, both at national and international levels. The second one is particular to phylogenetically driven taxonomic revisions of taxa covering large geographical regions, especially those using the techniques of molecular sequencing of nucleic acids, which required to have access to many specimens and tissues from widely distant origins, often from several or even many countries. The practice then developed to include as 'authors' the collectors of specimens and tissue samples, even when they had not participated in the laboratory work of sequencing, in the analysis of the data, the production of phylogenetic hypotheses, the taxonomic and nomenclatural analyses, and the writing of the manuscript. This extension of the concept of 'authorship' even goes further in some cases, to include $\mathrm{PhD}$ supervisors or advisors, directors of laboratories or heads of research teams within which the work was carried out, funders or sponsors whose financial help has facilitated or allowed the study, administrators who permitted the obtention of collection permits for specimens, or employees of natural history collections having facilitated the 
access to or the loan of specimens under their care but having usually not been collected by them ${ }^{1}$. In some of these cases, it is doubtful whether all the 'authors' of such papers would comply with 'Maxime Lamotte's criterion for inclusion as author of a scientific work', which requires to be able to present, explain and defend it at the tribune of a scientific meeting (Dubois 2015a: 26-27), and these 'expanded authorships' contribute to the current problems of zoological nomenclature that are related to authorship (Dubois 2008, 2015a).

These factors explain the recent increase in authorship of phylogenetic papers and also, but less strongly, that of taxonomic papers, as a growing proportion of the latter now tend to rely on molecular phylogenetic data. But, as shown by the data presented above, their impact on nomenclatural papers is very limited or even absent. Of the 74 papers dealing with biological nomenclature published in Bionomina, only two had more than four authors, and this is because these two works (Greuter et al. 2011, Dubois et al. 2019) did not discuss specific nomenclatural problems but presented collective proposals of major changes regarding the codes of nomenclature currently in force.

Nomenclatural works, when dissociated from the taxonomy to which their discipline applies, do not require large numbers of field collectors and laboratory technicians, nor do they depend on specific funding for the purchase or functioning of costly equipment. They require mainly brains and plenty of careful working time. Authors of such papers are real authors in the traditional sense of the term, not collectors of specimens, technicians or directors of theses or laboratories. For their publication, such highly specialised works need journals edited by scientists knowledgeable in the difficult field of biological nomenclature and willing to devote enough time and work to a meticulous analysis of the tricky problems of this discipline. Bionomina is such a journal.

\section{Acknowledgements}

For their comments on a first draft of this paper, we are grateful to Alessandro Minelli (Deputy Editor of Bionomina; Padova, Italy), Zhi-Qiang Zhang (Managing Editor of Bionomina; Auckland, New Zealand), Erna Aescht (Linz, Austria), Aaron M. Bauer (Villanova, USA), Thierry Frétey (SaintMaugan, France) and Ivan Löbl (Genève, Switzerland).

\section{References}

Aescht, E. (2018) Reflecting on a theory of biological nomenclature (onymology). Alytes, 36 (1-4): $212-237$.

Boero, F. (2010) The study of species in the era of biodiversity: a tale of stupidity. Diversity, 2: $115-126 .<$ https://doi. org/10.3390/d2010115>.

Dubois, A. (2005) Proposed Rules for the incorporation of nomina of higher-ranked zoological taxa in the International Code of Zoological Nomenclature. 1. Some general questions, concepts and terms of biological nomenclature. Zoosystema, 27 (2): 365-426. <https://doi.org/10.11646/zootaxa.1337.1.1>.

Dubois, A. (2008) A partial but radical solution to the problem of nomenclatural taxonomic inflation and synonymy load. Biological Journal of the Linnean Society, 93: 857-863. $<$ https://doi.org/10.1111/j.1095-8312.2007.00900.x>.

Dubois, A. (2010) Bionomina, a forum for the discussion of nomenclatural and terminological issues in biology. Bionomina, 1: $1-10 .<$ https://doi.org/10.11646/bionomina.1.1.1>.

Dubois, A. (2011) A zoologist's viewpoint on the Draft BioCode. Bionomina, 3: 45-62. <https://doi.org/10.11646/ bionomina.3.1.4>.

Dubois, A. (2015a) Zoological nomina in the century of extinctions: new proposals. Bionomina, 8: 11-53. <https://doi.

1 On the other hand, as aptly remarked by Boero (2010: 124), few of these recent papers acknowledge, through granting them with co-authorship of such papers, the help provided, usually for free, by taxonomists to solve the nomenclatural problems encountered during such studies, as this help is often considered 'granted' and poorly valued. 
org/10.11646/bionomina.8.1.2>.

Dubois, A. (2015b) The Duplostensional Nomenclatural System for higher zoological nomenclature. Dumerilia, 5: 1108.

Dubois, A., Bauer, A. M., Ceríaco, L. M. P., Dusoulier, F., Frétey, T., Löbl, I., Lorvelec, O., Ohler, A., Stopiglia, R. \& Aescht, E. (2019) The Linz Zoocode project: a set of new proposals regarding the terminology, the Principles and Rules of zoological nomenclature. First report of activities (2014-2019). Bionomina, 17: 1-111. <https://doi. org/10.11646/bionomina.17.1.1>.

Greuter, W., Garrity, G., Hawksworth, D. L., Jahn, R., Kirk, P. M., Knapp, S., McNeill, J., Michel, E., Patterson, D. J., Pyle, R. \& Tindall, B. J. (2011) Draft BioCode (2011). Principles and Rules regulating the naming of organisms. New draft, revised in November 2010. Bionomina, 3: 26-44. <https://doi.org/10.11646/bionomina.3.1.3>.

Kuhn, J. H. \& Wahl-Jensen, V. (2010) Being obsessive-compulsive about terminology and nomenclature is not a vice, but a virtue. Bionomina, 1: 11-14. < https://doi.org/10.11646/bionomina.1.1.2>.

Melville, R. V. (1995) Towards stability in the names of animals. London (International Trust for Zoological Nomenclature): $\mathrm{i}-\mathrm{xi}+1-92$.

Zhang, Z.-Q. (2007) A forum for the discussion of issues in zoological taxonomy. Zootaxa, 1407: 1-2. <https://doi. org/10.11646/zootaxa.1407.1.1>.

Submitted: 7 May 2021. Accepted: 13 May 2021. Published: 3 June 2021. Corresponding Editor: Zhi-Qiang Zhang. 


\section{APPENDIX 1. List OF THE PAPERS PUBLISHED IN VOLUMES 1 TO 20 OF BIONOMina}

Number 1. 24 December 2010. 5 papers. 60 pages.

[01-01] Dubois Alain (2010) Bionomina, a forum for the discussion of nomenclatural and terminological issues in biology. Bionomina, 1: 1-10.

[01-02] KuHN Jens H. \& WAHL-JENSEN Victoria (2010) Being obsessive-compulsive about terminology and nomenclature is not a vice, but a virtue. Bionomina, 1: 11-14.

[01-03] KLuge Nikita Julievich (2010) Circumscriptional names of higher taxa in Hexapoda. Bionomina, 1: 15-55.

[01-04] Bour Roger (2010) Constant Duméril's Zoologie Analytique was published in 1805. Bionomina, 1: 56-57.

[01-05] HoQuET Thierry (2010) Why terms matter to biological theories: the term 'origin' as used by Darwin. Bionomina, 1: 58-60.

Number 2. 18 February 2011. 1 paper. 104 pages.

[02-06] Dubois Alain (2011a) The International Code of Zoological Nomenclature must be drastically improved before it is too late. Bionomina, 2: 1-104.

Number 3. 21 April 2011. 6 papers. 76 pages.

[03-07] HoQUET Thierry (2011) Translating natural selection: true concept, but false term? Bionomina, 3: $1-23$.

[03-08] Hawksworth David L. (2011) Introducing the Draft BioCode (2011). Bionomina, 3: 2425.

[03-09] Greuter Werner, Garrity George, Hawksworth David L., Jahn Regine, Kirk Paul M., Knapp Sandra, McNeill John, Michel Ellinor, Patterson David J., Pyle Richard \& Tindall Brian J. (2011) Draft BioCode (2011). Principles and Rules regulating the naming of organisms. New draft, revised in November 2010. Bionomina, 3: 26-44.

[03-10] Dubois Alain (2011b) A zoologist's viewpoint on the Draft BioCode. Bionomina, 3: 45-62.

[03-11] Aescht Erna (2011) Viewing the Draft BioCode as a protistologist and museum employee. Bionomina, 3: 63-70.

[03-12] DuBoIs Alain (2011c) The rich but confusing terminology of biological nomenclature: a first step towards a comprehensive glossary. Bionomina, 3: 71-76.

\section{Number 4. 22 December 2011. 4 papers. 75 pages.}

[04-13] Vogt Lars (2011) Signs and terminology. Science caught between language and perception. Bionomina, 4: 1-41.

[04-14] HindLEY Philip (2011) The language of evolution: sources of misconception in descriptions of evolutionary processes in non-specialised scientific discourse. Bionomina, 4: 42-64.

[04-15] SHIPUNOV Alexey (2011) The problem of hemihomonyms and the on-line hemihomonyms database $(H H D B)$. Bionomina, 4: 65-72.

[04-16] DuBois Alain (2011d) The multiple meanings of ancient zoological terms. Bionomina, 4 : $73-75$.

Number 5. 30 March 2012. 2 papers. 80 pages.

[05-17] EPSTEIN Mark (2011d) Nomenclature, terminology and language. Bionomina, 5: 1-56.

[05-18] Dubois Alain (2012) The distinction between introduction of a new nomen and subsequent use of a previously introduced nomen in zoological nomenclature. Bionomina, 5: 57-80. 
Number 6. 28 June 2013. 2 papers. 80 pages.

[06-19] Dubors Alain (2013) Zygoidy, a new nomenclatural concept. Bionomina, 6: 1-25.

[06-20] Kisima Taizo \& Hoquet Thierry (2010) Translating 'natural selection' in Japanese: from 'shizen tôta' to 'shizen sentaku', and back? Bionomina, 6: 26-48.

[06-21] LAMBERTz Markus (2013) Notes on the original description of the maned three-toed sloth, Bradypus torquatus (Mammalia, Pilosa, Bradypodidae), by Johann Karl Wilhelm Illiger in 1811. Bionomina, 6: 49-51.

[06-22] Dubois Alain \& Berkani Mohamed (2013) The misleading use of the terms parent, child, ancestor and descendant in databases dealing with biological evolution and taxonomy. Bionomina, 6: $52-56$.

\section{Number 7. 6 June 2014. 2 papers. 64 pages.}

[07-23] NaOmi Shun-Ichiro (2014) Proposal of an integrated framework of biological taxonomy: a phylogenetic taxonomy, with the method of using names with standard endings in clade nomenclature. Bionomina, 7: 1-44.

[07-24] Dubois Alain, Nemésio André \& Bour Roger (2014) Primary, secondary and tertiary syntypes and virtual lectotype designation in zoological nomenclature, with comments on the recent designation of a lectotype for Elephas maximus Linnaeus, 1758. Bionomina, 7: 45-64.

\section{Number 8. 18 June 2015. 3 papers. 56 pages.}

[08-25] Dubois Alain (2015a) Further proposals about higher zoological nomenclature, and a lesson of humility: the solution to a recent controversy about the authorship and date of the nomen Amphibia had already been published one century ago. Bionomina, 8: 1-10.

[08-26] Dubois Alain (2015b) Zoological nomina in the century of extinctions: new proposals. Bionomina, 8: 11-53.

[08-27] LöBL Ivan (2015a) On inconsistency in, and undesirable side effects of the International Code of Zoological Nomenclature. Bionomina, 8: 54-56.

\section{Number 9. 24 December 2015. 5 papers. 53 pages.}

[09-28] Vlachos Evangelos (2015) Forming taxon names from Greek words. Bionomina, 9: 1-26.

[09-29] Dubois Alain (2015c) What is an anonymous publication? Is the International Code of Zoological Nomenclature anonymous? Bionomina, 9: 27-34.

[09-30] LöBL Ivan (2015b) Stability under the International Code of Zoological Nomenclature: a bag of problems affecting nomenclature and taxonomy. Bionomina, 9: 35-40.

[09-31] Dubois Alain \& OHLer Annemarie (2015) An often overlooked Rule of the Code, and its bearing on the authorship and date of the nomen Proteidae (Amphibia, Urodela). Bionomina, 9: 41-49.

[09-32] Woodman Neal (2015) On the original description of the Sacred Shrew, Sorex religiosa I. Geoffroy Saint-Hilaire, 1826 [nec 1827] (Mammalia: Soricidae). Bionomina, 9: 50-53.

\section{Number 10. 11 November 2016.5 papers. 75 pages.}

[10-33] Van Regenmortel Marc H. V. (2016) Classes, taxa and categories in hierarchical virus classification: a review of current debates on definitions and names of virus species. Bionomina, 10: $1-21$.

[10-34] Dubois Alain, Frétey Thierry \& OHLER Annemarie (2016) The nomenclatural status of the amphibian nomina published by Luuc Bauer from 1985 to 1994, with comments on the Rules of the Code concerning the techniques of printing. Bionomina, 10: 22-54.

[10-35] Rusin Mikhail, Ghazali Maria \& Seminikhina Maria (2016) Notes on the nomenclature of 
Sicista Griffith, 1827 (Rodentia: Sminthidae). Bionomina, 10: 55-60.

[10-36] Busack Stephen D., Salvador Alfredo, Bauer Aaron M. \& Kaiser Hinrich (2016) Darevskia and Iberolacerta (Reptilia, Lacertidae): Arribas, 1997 or 1999? The correct dating of two nomenclatural acts affecting Palearctic lizards, and validation of the name Caucasilacerta Harris, Arnold \& Thomas, 1998. Bionomina, 10: 61-73.

[10-37] Wellington Ross (2016) Acanthophis cryptamydros Maddock, Ellis, Doughty, Smith \& Wüster, 2015 is an invalid junior synonym of Acanthophis lancasteri Wells \& Wellington, 1985 (Squamata, Elapidae). Bionomina, 10: 74-75.

\section{Number 11. 4 March 2017. 3 papers. 78 pages.}

[11-38] Dubois Alain (2017a) The nomenclatural status of Hysaplesia, Hylaplesia, Dendrobates and related nomina (Amphibia, Anura), with general comments on zoological nomenclature and its governance, as well as on taxonomic databases and websites. Bionomina, 11: 1-48.

[11-39] Dubois Alain, Duellman William E. \& Ohler Annemarie (2017) Taxonomic and nomenclatural notes on the subfamily Acridinae of the family Hylidae (Amphibia, Anura). Bionomina, 11: 49-61.

[11-40] Rizzato Pedro P. \& Bockman Flávio (2017) Unraveling a 150 years old controversy: Calamoichthys Smith, 1866 is the valid name for the African Reedfish (Cladistii: Polypteriformes), with comments about the availability of involuntarily proposed zoological names. Bionomina, 11: 62-78.

\section{Number 12. 25 March 2017. 8 papers. 85 pages.}

[12-41] EPSTEIN Mark (2011d) Specimens and zoological nomenclature. Bionomina, 12: 1-3.

[12-42] Dubois Alain (2017b) The need for reference specimens in zoological taxonomy and nomenclature. Bionomina, 12: 4-38.

[12-43] LöBL Ivan (2017) Assessing biodiversity: a pain in the neck. Bionomina, 12: 39-43.

[12-44] Aguiar Jonas José Mendes, Santos Jean Carlos \& Urso-Guimarães Maria Virginia (2017) On the use of photography in science and taxonomy: how images can provide a basis for their own authentication. Bionomina, 12: 44-47.

[12-45] OrRico Victor G. D. (2017) Photography-based taxonomy is still really inadequate, unnecessary, and potentially harmful for biological sciences. A reply to Thorpe (2017). Bionomina, 12: 48-51.

[12-46] Raposo Marcos André \& KIRWAN Guy M. (2017) What lies beneath the controversy as to the necessity of physical types for describing new species? Bionomina, 12: 52-56.

[12-47] GRANDCOLAS Philippe (2017) Loosing the connection between the observation and the specimen: a by-product of the digital era or a trend inherited from general biology? Bionomina, 12: $57-62$.

[12-48] Dubois Alain $(2017 c)$ Diagnoses in zoological taxonomy and nomenclature. Bionomina, 12: 63-85.

\section{Number 13. 20 December 2018. 6 papers. 73 pages.}

[13-49] Kury Adriano B. (2018) Familial nomina in harvestmen (Arachnida, Opiliones). Bionomina, 13: $1-27$.

[13-50] Desutter-Grandcolas Laure, Hugel Sylvain, Goutte Sandra \& Robillard Tony (2018) Reflections on the growing use of sounds in systematics and synecology: why an acoustic signal cannot become an onomatophore. Bionomina, 13: 28-36.

[13-51] Frétey Thierry, Dewynter Maël \& OHLER Annemarie (2018) Onymotopes in zoological nomenclature: some additional terms, with fixation of a lectonymotope for Xenopus petersii 
Bocage, 1895 (Amphibia, Anura). Bionomina, 13: 37-50.

[13-52] Dubois Alain, FréTEY Thierry \& OHLER Annemarie (2018) The Relictus case: it is high time that taxonomists follow the Code's requirements for nomenclatural availability and validity of new zoological nomina. Bionomina, 13: 51-64.

[13-53] Pinna Pedro H., Fernandes Daniel S. \& Passos Paulo (2018) If you choose not to decide you still have made a choice. Bionomina, 13: 65-68.

[13-54] GIPPOLITI Spartaco (2018) Natural history collecting and the arrogance of the modern Ark researcher. Bionomina, 13: 69-73.

\section{Number 14. 25 February 2019. 1 paper. 68 pages.}

[14-55] Dubois Alain \& OHLER Annemarie (2019) The nomina Anura, Urodela, Ecaudata and Caudata, credited to 'Fischer von Waldheim, 1813', do not exist, with comments on the nomenclature of higher zoological taxa and on the authorships and dates of other amphibian nomina. Bionomina, 14: $1-68$.

\section{Number 15.2 July 2019.8 papers. 73 pages.}

[15-56] FrÉTEY Thierry \& DubOIS Alain (2019) The authorship and date of five generic nomina of Squamata and Amphibia published by Cuvier (1816, 1829), with recourse to and comments on twenty Articles of the Code. Bionomina, 15: 1-36.

[15-57] Cazzaniga Néstor J., Cañón Carola \& Pardiñas Ulyses F. J. (2019) The availability, authorships and dates of tribal names in the Sigmodontinae (Rodentia, Cricetidae) current classification. Bionomina, 15: 37-50.

[15-58] KURY Adriano B. (2019) Obscure priority: on the authorship of the nomen Sironidae (Arachnida, Opiliones). Bionomina, 15: 51-54.

[15-59] Salamatin Rusłan (2019) A new replacement name for Vitta Burt, 1938 (Platyhelminthes, Cestoda, Cyclophyllidea, Dilepididae). Bionomina, 15: 55-58.

[15-60] Dubois Alain \& SERET Bernard (2019) A justified emendation for a specific nomen of shark (Chondrichthyes), with comments on some Articles of the Code. Bionomina, 15: 59-62.

[15-61] Daniel Gimo (2019) The nomenclatural status of the generic nomina Epirinus Dejean, 1833 and Epirhinus Agassiz, 1846 (Coleoptera, Scarabaeidae, Scarabaeinae). Bionomina, 15: 63-65.

[15-62] CASANOVAS-VILAR Isaac (2019) The correct spelling of the nomen of the Yunnan giant flying squirrel Petaurista yunanensis Anderson, 1875 (Rodentia, Sciuridae). Bionomina, 15: 66-68.

[15-63] Sherwood Danniella, Gabriel Ray \& Longhorn Stuart J. (2019) A new synonymy in the genus Homoeomma Ausserer, 1871 (Araneae, Theraphosidae), with comments on potential homonymy. Bionomina, 15: 69-73.

\section{Number 16. 2 December 2019. 4 papers. 87 pages.}

[16-64] Minelli Alessandro (2019) Zoological nomina with typus or typicus as the specific epithet. Bionomina, 16: 1-21.

[16-65] FRÉTEY Thierry (2019) Capitalised epithets in the works of Linnaeus (1758-1767): findings and consequences in herpetology. Bionomina, 16: 22-45.

[16-66] SHEIKo Boris A. (2019) Comments on the nomenclature of genus- and family-series taxa of notothenioid fishes (Perciformes, Notothenioidei). Bionomina, 16: 46-82.

[16-67] Entiauspe-Neto Omar M. \& Loebmann Daniel (2019) Taxonomic status of Chironius laurenti Dixon, Wiest \& Cei, 1993 and of the longforgotten Chironius dixoni Wiest, 1978 (Squamata, Serpentes). Bionomina, 16: 83-87. 


\section{Number 17. 17 December 2019. 1 paper. 111 pages.}

[17-68] Dubois Alain, Bauer Aaron M., Ceríaco Luis M. P., Dusoulier François, Frétey Thierry, LöBl Ivan, Lorvelec Olivier, Ohler Annemarie, Stopiglia Renata \& Aescht Erna (2019) The Linz Zoocode project: a set of new proposals regarding the terminology, the Principles and Rules of zoological nomenclature. First report of activities (2014-2019). Bionomina, 17: 1-111.

\section{Number 18. 3 February 2020. 3 papers. 56 pages.}

[18-69] Dubois Alain (2020a) Allocation of nomina to taxa in zoological nomenclature. Bionomina, 18: $1-43$.

[18-70] Dubois Alain (2020b) The status regarding publication date and availability of taxonomic works published online without proper Zoobank registration. Bionomina, 18: 44-55.

[18-71] Wesolowska Wanda (2020) Authorship of the generic name Pochytoides (Araneae, Salticidae). Bionomina, 18: 56.

\section{Number 19. 10 September 2020. 7 papers. 115 pages.}

[19-72] DubOis Alain \& FrÉTEY Thierry (2020a) Herpetological higher taxa nomina. 1. Introduction and methodology. Bionomina, 19: 1-56.

[19-73] FrÉTEY Thierry (2020) Patronymic particle and bibliographic citation. Bionomina, 19: 5763.

[19-74] KURY Adriano B. (2020) Incorrect authorship assignments and repeated specific epithets: five cases of the use of homographs by Roewer in harvestmen (Arachnida, Opiliones). Bionomina, 19: 64-76.

[19-75] Kury Adriano B. \& Mendes Amanda C. (2020) Grammatical gender and corrections of the nomina of the species of Larifuga Loman, 1898 (Opiliones, Triaenonychidae). Bionomina, 19: 77-85.

[19-76] HoLOvaCHOv Oleksandr (2020) The nomenclatural status of new nematode nomina proposed in 1993 in the doctoral thesis of Christian Bussau, entitled Taxonomische und ökologische Untersuchungen an Nematoden des Peru-Beckens (Nematoda). Bionomina, 19: 86-99.

[19-77] Sanamyan Karen \& Sanamyan Nadya (2020) Comments on the nomenclatural status and validity of several family-series nomina in Actiniaria (Cnidaria, Anthozoa). Bionomina, 19: 100109.

[19-78] Dubois Alain \& DAVID Patrick (2020) The nomenclatural status of Zaocys carinatus Günther, 1864 (Squamata, Serpentes). Bionomina, 19: 110-115.

\section{Number 20. 31 December 2020. 5 papers. 56 pages.}

[20-79] Dubois Alain \& FrÉTEY Thierry (2020b) Herpetological higher taxa nomina. 2. Anura Duméril, 1805. Bionomina, 20: 1-16.

[20-80] Dubois Alain \& FréTEY Thierry (2020c) Herpetological higher taxa nomina. 3. Urodela Duméril, 1805. Bionomina, 20: 17-35.

[20-81] Dubois Alain \& FréTEY Thierry (2020d) Herpetological higher taxa nomina. 4. Batrachia Brongniart, 1800. Bionomina, 20: 36-46.

[20-82] Kaiser Hinrich, Thomson Scott A. \& Shea Glen M. (2020) Nawaran Esquerré, Donnellan, Brennan, Lemmon, Lemmon, Zaher, Grazziotin \& Keogh, 2020 is an invalid junior synonym of Nyctophilopython Wells \& Wellington, 1985 (Squamata, Pythonidae): simple priority without Zoobank pre-registration. Bionomina, 20: 47-54.

[20-83] GREENFIELD Tyler (2020) The authorship of the name of the megatooth shark Carcharocles (Lamniformes, Otodontidae). Bionomina, 20: 55-56. 


\section{Appendix 2. Tables.}

TABLE 1. Numbers of papers and pages published in issues 1-20 of Bionomina, and their numbers of authors and of their countries and regions of work.

\begin{tabular}{ccccccc}
\hline Year & Issues & N papers & N pages & N authors & N countries & N regions \\
\hline 2010 & 1 & 5 & 60 & 6 & 3 & 2 \\
2011 & $2-4$ & 11 & 255 & 21 & 5 & 2 \\
2012 & 5 & 2 & 80 & 2 & 2 & 2 \\
2013 & 6 & 4 & 56 & 5 & 3 & 2 \\
2014 & 7 & 2 & 64 & 4 & 3 & 3 \\
2015 & $8-9$ & 8 & 109 & 9 & 4 & 3 \\
2016 & 10 & 5 & 75 & 12 & 6 & 3 \\
2017 & $11-12$ & 11 & 163 & 17 & 5 & 3 \\
2018 & 13 & 6 & 73 & 15 & 3 & 2 \\
2019 & $14-17$ & 14 & 339 & 32 & 14 & 4 \\
2020 & $18-20$ & 15 & 227 & 24 & 7 & 4 \\
$2010-2020$ & $1-20$ & 83 & 1501 & 88 & 19 & 6 \\
\hline
\end{tabular}

TABLE 2. Numbers of authors of papers published in issues 1-20 of Bionomina according to their countries and regions of work.

\begin{tabular}{|c|c|c|c|c|}
\hline Region & $\mathrm{N}$ countries/region & $\mathrm{N}$ authors/region & Countries & $\mathrm{N}$ authors/country \\
\hline Africa & 1 & 1 & South Africa & 1 \\
\hline America (North) & 1 & 13 & USA & 13 \\
\hline \multirow{3}{*}{ America (South) } & \multirow{3}{*}{3} & \multirow{3}{*}{22} & Argentina & 3 \\
\hline & & & Brazil & 18 \\
\hline & & & Ecuador & 1 \\
\hline Asia & 1 & 2 & Japan & 2 \\
\hline \multirow{12}{*}{ Europe } & \multirow{12}{*}{12} & \multirow{12}{*}{48} & Austria & 1 \\
\hline & & & France & 18 \\
\hline & & & Germany & 5 \\
\hline & & & Italy & 2 \\
\hline & & & Poland & 2 \\
\hline & & & Portugal & 1 \\
\hline & & & Russia & 5 \\
\hline & & & Spain & 2 \\
\hline & & & Sweden & 1 \\
\hline & & & Switzerland & 1 \\
\hline & & & UK & 8 \\
\hline & & & Ukraine & 2 \\
\hline Oceania & 1 & 2 & Australia & 2 \\
\hline Total & 19 & 88 & 19 & 88 \\
\hline
\end{tabular}


TABLE 3. Main zoological higher taxa concerned by the 40 papers dealing with practical nomenclatural problems published in issues 1-20 of Bionomina (one paper covered two higher taxa and another one four higher taxa).

\begin{tabular}{|c|c|}
\hline Main group & Number of papers \\
\hline ARTHROPODA: ARACHNIDA & 6 \\
\hline ARTHROPODA: INSECTA & 2 \\
\hline CNIDARIA & 1 \\
\hline Nematoda & 1 \\
\hline Platyhelminthes & 1 \\
\hline Vertebrata: ACtinOPTERygiI & 2 \\
\hline VERTEBRATA: AMPHIBIA & 13 \\
\hline Vertebrata: CheloniI & 2 \\
\hline VerTEBRATA: ChONDRICHTHYES & 2 \\
\hline Vertebrata: Crocodilia & 1 \\
\hline Vertebrata: Mammalia & 6 \\
\hline VERTEBRATa: SQuamata & 7 \\
\hline
\end{tabular}

TABLE 4. Main topics and subject addressed in the 66 papers dealing with zoological nomenclature published in issues 1-20 of Bionomina.

[SS], species-series; [GS], genus-series; [FS], family-series; [CS], genus-series.

\begin{tabular}{|c|c|c|}
\hline Main topic & Subject & Number of papers \\
\hline \multirow{4}{*}{ General } & The Code & 56 \\
\hline & The Commission & 29 \\
\hline & Use of the Plenary Power & 15 \\
\hline & Nomenclatural terminology & 30 \\
\hline \multirow{4}{*}{ Nominal-series } & Species-series & 40 \\
\hline & Genus-series & 31 \\
\hline & Family-series & 25 \\
\hline & Class-series & 19 \\
\hline \multirow{8}{*}{$\begin{array}{l}\text { Nomenclatural availability } \\
\text { of works and nomenclatural } \\
\text { novelties, nominal-series } \\
\text { assignment }\end{array}$} & General & 50 \\
\hline & Assignment to nominal-series and ranks & 25 \\
\hline & Technology of publication & 6 \\
\hline & Authorship & 41 \\
\hline & Diagnosis & 29 \\
\hline & Availability of theses & 3 \\
\hline & Online publications & 4 \\
\hline & Online registration & 10 \\
\hline \multirow{4}{*}{ Taxonomic allocation of nomina } & General & 25 \\
\hline & Onomatophores (types) & 46 \\
\hline & Onomatostases & 7 \\
\hline & Collections, specimens and photographs & 17 \\
\hline
\end{tabular}


TABLE 4. (Continued)

\begin{tabular}{|c|c|c|}
\hline Main topic & Subject & Number of papers \\
\hline \multirow{5}{*}{$\begin{array}{c}\text { Nomenclatural validity of } \\
\text { nomina and nomenclatural acts }\end{array}$} & General & 40 \\
\hline & Synonymy & 36 \\
\hline & Homonymy & 31 \\
\hline & Usage & 32 \\
\hline & Reversal of precedence & 18 \\
\hline \multirow{3}{*}{ Spelling } & General & 33 \\
\hline & Etymology & 24 \\
\hline & Grammatical gender & 10 \\
\hline \multirow{4}{*}{ Recommendations and ethics } & Recommendations & 25 \\
\hline & Conservation biology & 9 \\
\hline & Ethics & 5 \\
\hline & 'Taxonomic vandalism' & 2 \\
\hline \multirow{3}{*}{ Other nomenclatural systems } & Phylocode & 9 \\
\hline & Biocode & 4 \\
\hline & Ostensional Nomenclatural Systems & 8 \\
\hline \multirow{10}{*}{$\begin{array}{c}\text { Taxonomic and nomenclatural } \\
\text { novelties }\end{array}$} & New taxon and nomen (poieonym) [GS] & 1 \\
\hline & New taxon and nomen (poieonym) [FS] & 2 \\
\hline & New taxon and nomen (poieonym) $[\mathrm{CS}]$ & 5 \\
\hline & New replacement nomen (neonym) [GS] & 1 \\
\hline & Lectotype (lectophoront) designation [SS] & 1 \\
\hline & Type species (nucleospecies) designation [GS] & 1 \\
\hline & New combination $[\mathrm{SS}]$ & 1 \\
\hline & Spelling emendation [GS] & 1 \\
\hline & Reversal of precedence under Article 23.9 [SS] & 4 \\
\hline & Sozodiaphonym validation $[\mathrm{CS}]$ & 5 \\
\hline
\end{tabular}

TABLE 5. Numbers of citations (retrieved from Google Scholar) of the 83 papers published in issues 1-20 of Bionomina.

\begin{tabular}{ccccccc}
\hline Issues and years & $\begin{array}{c}\text { Numbers } \\
\text { of papers }\end{array}$ & $\begin{array}{c}\text { Total } \\
\text { citations }\end{array}$ & $\begin{array}{c}\text { Range of citations } \\
\text { by paper }\end{array}$ & $\begin{array}{c}\text { First } \\
\text { quartile }\end{array}$ & $\begin{array}{c}\text { Second quartile } \\
\text { (median) }\end{array}$ & $\begin{array}{c}\text { Third } \\
\text { quartile }\end{array}$ \\
\hline $1-10(2010-2012)$ & 18 & 259 & $0-74$ & 2 & 6.5 & 11 \\
$11-20(2013-2020)$ & 65 & 359 & $0-58$ & 1 & 1 & 3 \\
\hline Total & 83 & 618 & $0-74$ & 7 & 8 \\
\hline
\end{tabular}


TABLE 6. Most cited papers (10 citations or more) published in issues 1-20 of Bionomina.

References [Issue number - Paper number] are listed in Appendix 1.

\begin{tabular}{|c|c|c|c|c|}
\hline Reference & $\begin{array}{l}\text { Number } \\
\text { of pages }\end{array}$ & $\begin{array}{c}\text { Number of } \\
\text { citations }\end{array}$ & $\begin{array}{c}\text { Theoretical, } \\
\text { practical or both }\end{array}$ & Main topic of paper \\
\hline [02-06] Dubois (2011a) & 104 & 74 & Both & Zoological nomenclature \\
\hline [11-38] Dubois (2017a) & 48 & 58 & Both & Zoological nomenclature \\
\hline [03-09] Greuter et al. (2011) & 19 & 53 & Theoretical & Biological nomenclature \\
\hline [01-03] Kluge (2010) & 41 & 35 & Both & Zoological nomenclature \\
\hline [05-18] Dubois (2012) & 24 & 27 & Both & Zoological nomenclature \\
\hline [12-42] Dubois (2017b) & 35 & 24 & Theoretical & Zoological nomenclature \\
\hline [12-47] Grandcolas (2017) & 6 & 20 & Theoretical & Zoological nomenclature \\
\hline [08-26] Dubois (2015b) & 43 & 19 & Theoretical & Zoological nomenclature \\
\hline $\begin{array}{c}\text { [10-33] Van Regenmortel } \\
\text { (2016) }\end{array}$ & 104 & 19 & Theoretical & Virus nomenclature \\
\hline [16-67] Dubois et al. (2019) & 111 & 19 & Theoretical & Zoological nomenclature \\
\hline [06-19] Dubois (2013) & 25 & 15 & Theoretical & Zoological nomenclature \\
\hline [12-44] Aguiar et al. (2017) & 4 & 13 & Theoretical & Zoological nomenclature \\
\hline [03-07] Hoquet (2011) & 23 & 11 & Practical & $\begin{array}{c}\text { Terminology, evolution, } \\
\text { translation }\end{array}$ \\
\hline [03-08] Hawksworth (2011) & 2 & 11 & Theoretical & Biological nomenclature \\
\hline [04-15] Shipunov (2011) & 8 & 11 & Practical & Biological nomenclature \\
\hline $\begin{array}{c}\text { [12-46] Raposo \& Kirwan } \\
\text { (2017) }\end{array}$ & 5 & 10 & Theoretical & Zoological nomenclature \\
\hline [14-55] Dubois \& Ohler (2019) & 68 & 10 & Both & Zoological nomenclature \\
\hline
\end{tabular}


TABLE 7. Comparison of the number of authors of the 83 papers published from December 2010 to December 2020 in issues 1-20 of Bionomina with the numbers of authors of papers published during the same period in the periodicals Zootaxa and Molecular and Phylogenetic Evolution.

For Bionomina, all the papers published in the journal were considered $(n=83)$.

For Zootaxa and Molecular Phylogenetics and Evolution, the first published papers of each month of the years 2011 to 2020 were considered $(n=120)$.

\begin{tabular}{|c|c|c|c|}
\hline Number of authors & Bionomina & Zootaxa & Molecular Phylogenetics and Evolution \\
\hline 1 & 51 & 21 & 5 \\
\hline 2 & 17 & 41 & 16 \\
\hline 3 & 11 & 26 & 22 \\
\hline 4 & 2 & 13 & 16 \\
\hline 5 & - & 3 & 22 \\
\hline 6 & - & 8 & 13 \\
\hline 7 & - & 2 & 10 \\
\hline 8 & - & 3 & 6 \\
\hline 9 & - & 1 & 2 \\
\hline 10 & 1 & - & 2 \\
\hline 11 & 1 & - & 2 \\
\hline 12 & - & 1 & 1 \\
\hline 13 & - & 1 & 1 \\
\hline 14 & - & - & - \\
\hline 15 & - & - & - \\
\hline 16 & - & - & 1 \\
\hline 17 & - & - & 1 \\
\hline Range & $1-11$ & $1-13$ & $1-17$ \\
\hline First quartile & 1 & 2 & 3 \\
\hline Second quartile (median) & 1 & 2 & 5 \\
\hline Third quartile & 2 & 4 & 6 \\
\hline Mode & 1 & 2 & 3 \\
\hline
\end{tabular}

